\title{
THE EFFECT OF POSTURE ON GAS EXCHANGE FOLLOWING CARDIAC SURGERY
}

\author{
Fred I. Rabow, "M.D., C.M., P. Dwane, ${ }^{\circ}$ M.D.,

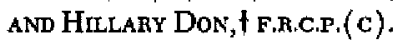

The chavge from the supine to the sitting position is associated with changes in factors which have conflicting effects on gas exchange. Cardiac output is decreased," tending to increase the alveolar to arterial gradient for oxygen $\left(\mathrm{AaDO}_{2}\right),{ }^{2}$ Functional residual capacity (FRC) increases, however, ${ }^{1}$ promoting better distribution of ventilation in the lung. In certain subjects, this enables more airways to remain open during normal breathing, and decreases $\mathrm{AaDO}_{2}{ }^{1}$

Patients in the postoperative period after cardiac surgery feel more comfortable in the semi-sitting position. It was the aim of our present study to see whether this is associated with any significant alteration in gas exchange, and whether one of the conflicting factors discussed above has a predominant effect.

\section{METHOD}

Nine male and three female patients were studied on the day following their operation. Mean age was 47 years, with a range of 23 to 57 years. The surgery was performed using extra-corporeal circulation and involved valve replacement, aortocoronary graft or closure of ventricular septal defects.

Cardiac output was measured in triplicate by a dye-dilution method using indocyanine green. The dye was injected through a central vein and sampled from a radial artery. A Waters system (XC 302 cuvette; D 400 densitometer) was used, with a 10 -inch recorder (Honeywell Electronik 194). Curves were analyzed using the Stewart-Hamilton semi-logarithmic replot technique.

Expired gas was collected over three minutes in a neoprene bag with a nonrebreathing valve of $35 \mathrm{ml}$ dead space. Arterial blood was collected simultaneously from an in-dwelling catheter in the radial artery into a heparinized syringe. Ali blood and gas analyses were by conventional electrodes (Instrumentation Laboratories 113 System). Alveolar oxygen partial pressure $\left(\mathbf{P}_{\mathrm{AO}_{2}}\right)$ was calculated from the following form of the alveolar air equation ${ }^{3}$ :

$$
\mathrm{PA}_{\mathrm{O}_{2}}=\mathrm{PI}_{\mathrm{O}_{2}}-\mathrm{Pa}_{\mathrm{CO}_{2}}\left(\mathrm{PI}_{\mathrm{O}_{2}}-\mathrm{P}_{\mathrm{E}_{2}}\right) / \mathrm{PE}_{\mathrm{CO}_{2}} \text {. }
$$

From the Department of Anaesthesia, Royal Victoria Hospital and McGill University, Montreal, P.Q., Canada.

- Resident, Department of Anaesthesia.

†Associate Professor, Present address, Depurtment of Anaesthesia, Peter Bent Brigham Hospital, Boston, Massachusetts 02115.

Supported by MRC (Canada). 
TABLE I

Gas exchange Results in the Supine, Horizontal Position, and With The Thunk AT AN ANGLE OF $35^{\circ}$

\begin{tabular}{|c|c|c|c|c|c|c|c|c|}
\hline \multirow[b]{2}{*}{ Patient } & \multicolumn{2}{|c|}{$\underset{\mathrm{mm} \mathrm{Hg}}{\mathrm{Pao}_{\mathrm{g}}}$} & \multicolumn{2}{|c|}{$\begin{array}{l}\operatorname{Aarog}_{\mathrm{g}} \\
\operatorname{mm} \mathrm{Hg}\end{array}$} & \multicolumn{2}{|c|}{$\begin{array}{l}\text { Cardiac } \\
\text { Output } \\
\text { L/ min. }\end{array}$} & \multicolumn{2}{|c|}{$\underset{\mathrm{maco}}{\mathrm{Pag}_{\mathbf{g}}}$} \\
\hline & Horizontal & $35^{\circ}$ & Horizontal & $35^{\circ}$ & Horizontal & $35^{\circ}$ & Horizontal & $35^{\circ}$ \\
\hline $\begin{array}{c}1 \\
2 \\
3 \\
4 \\
5 \\
6 \\
7 \\
8 \\
9 \\
10 \\
11 \\
12 \\
\text { Mean } \\
\mathrm{SD} \\
\mathrm{P}=\end{array}$ & $\begin{array}{r}123 \\
87 \\
75 \\
75 \\
58 \\
85 \\
82 \\
85 \\
85 \\
88 \\
68 \\
76 \\
82 \\
15\end{array}$ & $\begin{array}{r}111 \\
87 \\
74 \\
82 \\
59 \\
102 \\
52 \\
84 \\
79 \\
89 \\
67 \\
74 \\
82 \\
14\end{array}$ & $\begin{array}{r}152 \\
150 \\
191 \\
180 \\
208 \\
177 \\
135 \\
118 \\
153 \\
140 \\
169 \\
160 \\
162 \\
25\end{array}$ & $\begin{array}{l}163 \\
150 \\
181 \\
180 \\
208 \\
159 \\
128 \\
126 \\
160 \\
148 \\
159 \\
160 \\
160 \\
22\end{array}$ & $\begin{array}{l}5.4 \\
5.5 \\
3.8 \\
4.0 \\
3.8 \\
3.4 \\
4.1 \\
6.5 \\
7.4 \\
5.8 \\
4.5 \\
3.8 \\
4.8 \\
1.3\end{array}$ & $\begin{array}{l}4.9 \\
4.9 \\
3.8 \\
4.7 \\
3.6 \\
3.4 \\
3.6 \\
6.4 \\
8.1 \\
5.1 \\
4.8 \\
3.4 \\
4.7 \\
1.4\end{array}$ & $\begin{array}{r}43.5 \\
50.5 \\
44.0 \\
44.0 \\
46.0 \\
49.0 \\
44.5 \\
40.0 \\
37.0 \\
42.0 \\
39.0 \\
39.5 \\
43.3 \\
4.0 \\
\\
\end{array}$ & $\begin{array}{r}43.5 \\
51.0 \\
42.0 \\
43.5 \\
43.0 \\
43.0 \\
44.0 \\
38.0 \\
33.5 \\
41.0 \\
36.0 \\
37.5 \\
41.4 \\
4.5\end{array}$ \\
\hline
\end{tabular}

Note: The mean value and the standard deviation are given at the bottom of each colunn The significance was tested by the Student's test for paired differences.

The inspired gas was a preformed mixture of 40 per cent oxygen in nitrogen contained in a light-weight Neoprene bag.

Seven patients were studied first in the supine position and then with the patient tlexed at the hips so that the trunk made an angle of $35^{\circ}$ with the horizontal. In the remaining fivc patients the sequence was reversed. Fifteen minutes were allowed following a position change before measurements were made.

Systemic blood pressure was measured in each position by a sphygmomanometer.

\section{Results}

The change from supine to $35^{\circ}$ head up had in each case the effect of making the patient feel more comfortable and less dyspnoeic. The results for the gas exchange data are shown in Table $T$. Where mean values are given, the figures in parentheses indicate the standard deviation.

1. Horizontal position. Mean arterial oxygen tension $\left(\mathrm{Pa}_{0_{2}}\right)$ was $82( \pm 15) \mathrm{mm}$ $\mathrm{Hg}$. Mean alvcolar-arterial oxygen tension difference was $162( \pm 25) \mathrm{mm} \mathrm{Hg}$. This is considerably higher than in nomal subjects, but is in agreement with published data for the postoperative period following cardiac surgery. ${ }^{4}$ Mean cardiac output was 4.8 ( \pm 1.3 ) litres/minute. Mean arterial carbon dioxide tension (Paran) was $43.3 \mathrm{~mm} \mathrm{Hg}$.

2. Effect of change to $35^{\circ}$ head up. There was no significant alteration in $\mathbf{P a}_{\mathrm{O}_{2} \text {, }}$ $\mathrm{Aa}_{\mathrm{LO}_{2}}$ or cardiac output, when tested using the Student's test for paired differences. There was a small but statistically significant decrease in $\mathrm{Pa}_{\mathrm{a}_{1}}(\mathrm{P}=0.004)$ on adopting the $35^{\circ}$ head-up posture. 


\section{Discussion}

It has been postulated that the deflcit in gas exchange following cardiac surgery is due to atelectasis. ${ }^{5}$ Beecher in $1933^{7}$ showed that following abdominal surgery, functional residual capacity (FRC) was reduced. The significance of FRC is its relationship to "closing volume" (CV). In a normal subject, as lung volume is reduced from a total lung capacity (TLC), a volume of the lung is reached where airways start to close - the "closing volume." It has been shown to be of importance to gas exchange that FRC remains above $\mathrm{CV}$ during nomal breathing. ${ }^{1}$ The benefit of continuous positive pressure ventilation (CPPV) is possible by maintaining the lungs at an increased FRC and therefore minimizing atelectasis. ${ }^{7}$ Continuous positive pressure has in some patients the disadvantage of reducing cardiac output, ${ }^{8}$ presumably because of a raised intrapleural pressure. A second important complication of CPPV is the occurrence of pneumothorax. ${ }^{7}$

We wondered, therefore, whether the FRC could be increased by an alternative technique to CPPV - the simple mechanism of tilting the trunk into a head-up position. This would not have the technical problems associated with CPPV, nor the dangers of increased intrapleural pressure, although cardiac output is lowered in the head-up position. ${ }^{1}$ During gradual tilting, from supine to standing, the increase in FRC is about linearly related to the angle of thlt from the vertical to the horizontal."

Our results indicated that the manoeuvre of moving the patient from the supine to the $35^{\circ}$ position was not associated with a significant decrease in $\mathrm{Aa}_{\mathrm{DO}}$ nor cardiac output.

It is possible that gas exchange fails to improve because the angle of tilt of the patients is insufficient to alter the relationship of FRC to CV. Firstly in the presence of a lung with low compliance, position change will have less effect on FRC. Secondly CV may be so far above FRC that even the normal change in FRC would not place it above CV.

A curious finding for which we do not have an explanation is the small but consistent decrease in arterial carbon dioxide tension in the $35^{\circ}$ head-up position.

The subjective benefit which we found in each patient was not, therefore, associated with any significant improvement in gas exchange. Our results indicated that nursing patients in the postoperative period after cardiac surgery in a head-up position at $35^{\circ}$ to the horizontal does not impair their cardio-pulmonary status.

\section{SUMMARY}

Gas exchange and cardiac output was measured in twelve patients the day after cardiac surgery involving total cardio-pulmonary bypass. Measurements made with the trunk of the patient flexed at $35^{\circ}$ to the horizontal were compared with those made in the horizontal position.

There was no significant difference in arterial $\mathrm{P}_{0_{2}}$, alveolar-arterial oxygen gradient $\left(\mathrm{Aa}_{\mathrm{DO}_{2}}\right)$ or cardiac output. Arterial $\mathrm{P}_{\mathrm{CO}_{2}}$ decreased slightly but significantly in the $35^{\circ}$ head-up position.

We concluded that the $35^{\circ}$ head-up position could be safely used to make pa- 
tients subjectively more comfortable, but there was no evidence of any improvement in cardio-respiratory parameters.

\section{RÉSUMÉE}

Chez douze malades, le jour suivant de la chirurgie cardiaque, impliquant une circulation cardio-pulmonaire totale extracorporelle, nous avons mesuré les échanges gazeux et le débit cardiaque. Ces études ont été faites alors que les malades étaient assis ì $35^{\circ}$ par rapport à l'horizontale et une comparaison a été faite avec les résultats obtenus alors que les malades étaient en position horizontale.

On a noté peu de différence daris la $P_{\mathrm{O}_{2}}$ artérielle, la différence alvéolo-artérielle en oxygène $\left(\mathrm{Aa}_{\mathrm{DO}_{2}}\right.$ ) et le débit cardiaque. $\mathrm{La}^{\mathrm{CO}_{2}}$ a diminué légèrement mais de façon valable en position assise à $35^{\circ}$.

Nous concluons que la position assise à $35^{\circ}$ peut être acceptée pour le comfort subjectif des malades, mais qu'il n'existe pas d'évidence d'amélioration des paramètres cardio-respirataire.

\section{ACKNOWLEDCMENT}

We thank Dr. Ronald Gabel for performing the statistical analyses.

\section{REFERENCES}

1. Cfaic, D.B., Wahba, W.M., Don, H.F., Covtune, J.G., \& Becklake, M.R. "Closing volume" and its relationship to gas exchange in seated and supine positions. J. Appl. Physiol. 31: $717(1971)$

2. Philbin, D.M., Sulcryan, S.F., Bowhin, F.O, Malm, J.R., Papper, E.M. Postoperative hypoxemia: contribution of the cardiac output. Anesthesiology 32 : 136 (1970).

3. Nonn, J.F. Applied respiratory physiology with special reference to anaesthesia, London: Butterworth (1969).

4. Elolson, L.'I', DUKF II, J.F., \& Ellison, R.G. Pulmonary compliance following open-heart surgery and its relationship to ventilation and gas exchange. Supplement to Circulation, 25 and $26: 217$ (1967).

5. Hebley-WhYTe, J., Conning, H, Laver, M.B., Austen, W.G., \& Bendixen, H.H. Pulmonary ventilation - Perfusion relations after heart valve replacement or repair in man. J. Clin. Invest. 44: 406 ( 1965 )

6. BeEchen, H.K Effect af laparalomy on hug volume. Demanstration of a new type of pulmonary collapse. J. Clin. Invest. 12:651 (1933).

7. Kumaf, A. Falke, K.J., Geffin, B., Aldheige, C.F., Lavef, M.B., Lowenstein, E. \& Pontoppman, $\boldsymbol{H}$. Continuous positive-pressure ventilation jn acute respitatory failure. New Engl. J. Med. 283: 1430 (1970).

8. Lutch, J.S. \& Murfay, J.F. Continuous positive-pressure ventilation: effects on systemic oxygen transport and tissue axygenation. Ann. Int. Med. 76: 193 ( 1972 ).

9. Acostuni, E. \& Mead, J. in Handbook of Physiology, Respiration r: 398 (1964). 